\title{
Microbial plankton response to contrasting climatic conditions: insights from community structure, productivity and fraction stoichiometry
}

\author{
Manuel Villar-Argaiz ${ }^{1, *}$, Juan M. Medina-Sánchez ${ }^{1}$, Presentación Carrillo² \\ ${ }^{1}$ Departamento de Biología Animal y Ecología, Facultad de Ciencias, Universidad de Granada, 18071 Granada, Spain \\ ${ }^{2}$ Instituto del Agua, Universidad de Granada, 18071 Granada, Spain
}

\begin{abstract}
Climatic events are among the most important forces governing natural processes in ecosystems. Over a 3 yr period, we monitored changes in the hydrological, chemical and biological regimes of a high mountain lake severely affected by a drought that peaked in 1995. During the drought, the decrease in lake volume enhanced the contribution of the sediment to the lake nutrient budget. The community became more complex, with the appearance of ciliates and heterotrophic nanoflagellates, organisms rarely found prior to the drought. The impaired post-drought recovery of the zooplankton, which did not reach normal densities for this lake until 1997, resulted in a microbialdominated food web in 1996 and a classical grazing food web in 1997. Besides the species composition or abundance and the autotrophic to heterotrophic ratio, food web changes associated with the drought and atmospheric nutrient inputs were reflected in the stoichiometry and contribution of both bacteria and phytoplankton fractions to the planktonic particulate matter. Specific productivity measurements showed that cellular N:P ratios could be used to evaluate the growth conditions of phytoplankton but not of bacteria, indicating that an element other than P may limit bacteria growth. Assessments of phytoplankton and bacteria productivity and of the photosynthetic carbon release relative to bacteria demand in microcosms revealed that after a phosphorus pulse, the phytoplankton $\mathrm{N}: \mathrm{P}$ ratio determines the nature of the interaction between phytoplankton and bacteria as either commensalistic or competitive for inorganic P. If phytoplankton N:P is initially high (P-deficient algae), a $P$ pulse can reduce photosynthetic extracellular release (PER) and bacteria can experience C limitation, whereas if phytoplankton N:P is initially low (P-sufficient algae) and bacteria N:P is high, increased PER is observed and competition for inorganic P may occur.
\end{abstract}

KEY WORDS: Drought · Atmospheric depositions · Food web · Phytoplankton vs bacteria interaction · Productivity $\cdot$ Stoichiometry

\section{INTRODUCTION}

Understanding factors that control plankton dynamics has long been a central concern of ecologists. However, whereas the mechanisms behind the food web structure have been extensively studied (e.g. Polis \& Winemiller 1996), the impact of climate on plankton communities has only recently begun to be explored

*E-mail: mvillar@ugr.es
(Aebischer et al. 1990). There is increasing evidence of a causal chain linking meteorological, hydrological and ecological processes in lakes (Straile 2000). Furthermore, it is becoming increasingly clear that the physical and hydrological properties of lakes are directly influenced by meteorological forces, leaving behind a 'remarkable memory of climatic effects' (sensu Straile 2000) with consequences for the abundance and succession of the organisms that inhabit them. These effects may be particularly evident in closure-lakes (Marsh \& Lesack 1996) with no inlets or

() Inter-Research $2002 \cdot$ www.int-res.com 
outlets, where most of the water is exchanged as a result of meteorological processes. Droughts represent extreme conditions of rainfall and temperature that have drastic effects on ecosystems. The fact that climatic models for Europe predict more frequent and intense droughts at lower latitudes (Houghton et al. 1996) means that further experimental research is urgently required on the effects of climate on plankton production and dynamics in aquatic ecosystems.

The biological structure of ecosystems serves as an appropriate marker of the strength of the controls operating in planktonic food webs. Thus, it is commonly accepted that phytoplankton dominate the food base in the more productive eutrophic lakes, whereas heterotrophic biomass dominates in less productive lakes (del Giorgio \& Gasol 1995, Biddanda et al. 2001). It is likely that climatic forces are reflected in changes in the relative contribution of autotrophs and heterotrophs to total plankton biomass, which can reveal the patterns of resource versus consumer control within planktonic communities. More data on total autotrophic and heterotrophic biomass are needed to adequately address these issues.

As with other climatic forces, atmospheric inputs must be considered in order to understand the functioning of an ecosystem. It is now recognized that African dust is rich in nutrients and, by carrying phosphate and other nutrients, constitutes a major source of nutrients, particularly for oligotrophic systems (Cole et al. 1990). Thus, there is increasing evidence that many lakes in Europe (Psenner 1999), including the one under study (Sierra Nevada, Southern Spain), may be exposed to the influence of these African dust storms, which contain high levels of P (Krom et al. 1991). As in the case of the Mediterranean Sea (Löye-Pilot et al. 1986), the impact of the so-called 'red rains' in stimulating primary and bacterial production could be substantial in oligotrophic high mountain lakes. Nevertheless, it is not known to what extent these external nutrients, especially $\mathrm{P}$, are taken up by bacteria and algae.

Phytoplankton and bacteria constitute the living organic matter that relies on the mineral nutrients from the surrounding water to support their growth. It is commonly accepted that knowledge of these organisms' elemental composition provides insights into their nutrient demands and potential growth (Healey \& Hendzel 1980, Sterner 1995, Chrzanowski et al. 1996). Thus, the elemental ratios of the cells and the available substrates determine whether bacteria or phytoplankton can be limited by either of these elements. For example, given excess of all other elements, bacteria will be limited by $\mathrm{P}$ when its $\mathrm{N}: \mathrm{P}$ ratio is lower than that of the available substrate but limited by $\mathrm{N}$ when its N:P ratio is higher than that of the available substrate
(Tezuka 1990). Important information on the relative sensitivity of lake ecosystems to potential environmental changes can be provided by evaluating how elemental composition and biomass contribution of bacteria and phytoplankton are modified by scenarios of intensive drought periods or atmospheric $\mathrm{P}$ loads. While elemental ratios have been routinely used to describe the physiological status of plankton, few studies have simultaneously dealt with the elemental content of bacteria and phytoplankton in natural conditions. Even fewer studies have related elemental composition to physiological properties such as nutrient uptake (but see Vadstein \& Olsen 1989, Elser et al. 1995) or the nature of bacterial and phytoplankton interaction. To date, the aquatic literature has generally agreed upon 2 possible scenarios for the relationship between bacteria and phytoplankton in nature: a competitive interaction for inorganic N and P (Currie \& Kalff 1984, Thingstad et al. 1993, Brett et al. 1999), or a commensalistic interaction where bacterial growth rates are ruled by the available photosynthetic organic carbon (e.g. Cole et al. 1982). Nevertheless, despite the abundance of valuable research, studies that address the temporal variability of these scenarios are still required, exploring the additional perspectives that elemental stoichiometry can offer into the nature of the interaction between phytoplankton and bacteria.

In the present study, we examined the impacts of climate events, droughts and atmospheric P inputs on the planktonic food web of a high mountain lake. In order to meet this objective, we analyzed the structure of the food web, and the specific productivity and elemental composition of the phytoplankton and bacterial fractions over a $3 \mathrm{yr}$ period of contrasting climatic conditions. In addition, the importance of atmospheric nutrient inputs for bacteria and phytoplankton productivity and their interaction was further examined by experimental phosphorus amendments at different N:P ratios.

\section{MATERIALS AND METHODS}

Study site. La Caldera is a small oligotrophic lake of about 2 ha located in Sierra Nevada (Southern Spain) at $3050 \mathrm{~m}$ (above sea level). The lake is fishless, lacks littoral vegetation, has highly transparent water (Secchi visibility reaching the bottom), and a

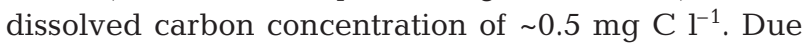
to its location in a glacial cirque above tree-line and the absence of visible waterflow inputs or outputs, La Caldera is highly sensitive to any significant variation in the precipitation regime (Villar-Argaiz et al. 2001). The zooplankton community is dominated by the calanoid copepod Mixodiaptomus laciniatus, and 
there are virtually no large cladocerans present in the community. Further characteristics of this site have been discussed elsewhere (Medina-Sánchez et al. 1999).

Sampling and laboratory procedures. Field samples were taken at 5 to $10 \mathrm{~d}$ intervals during the ice-free periods of 1995 through 1997. Maximum depth and temperature were measured using a YSI probe, and light penetration in the lake was measured on each sample date with a spherical radiation sensor Li-Cor, LI 193SA. Sampling was conducted with a 61 Van Dorn sampler at the deepest central station at 2 depths $(0.5$ and $1 \mathrm{~m})$ in 1995 and at 4 depths $(0.5,5,8$ and $10.5 \mathrm{~m})$ in 1996-97. Water samples were taken for bacteria $(20$ $\mathrm{ml})$, phytoplankton $(130 \mathrm{ml})$, ciliates $(1 \mathrm{l})$ and zooplankton (at least 12 l) counts and for chlorophyll a (chl a) (3 to 5 l) and chemical determinations (total nitrogen and phosphorus and filtered through $0.45 \mu \mathrm{m}$ for total dissolved nitrogen and phosphorus).

Bacterial abundance was determined by epifluorescence microscopy from bacterial samples that were preserved with $2 \%$ (final conc.) neutralized and $0.2 \mu \mathrm{m}$ filtered formaldehyde, stained with the fluorochrome DAPI (Porter \& Feig 1980), and filtered onto $0.2 \mu \mathrm{m}$ pore size black Nuclepore filters. The bacterial biomass was calculated according to the allometric relationship between carbon content $(C)$ and cell volume $(V)$ reported by Norland (1993):

$$
C=120 \times V^{0.72} \times 10^{-9}\left(\mu \mathrm{g} \mathrm{C} \text { cell }^{-1}\right)
$$

The cell volume was calculated by approximating each cell to its geometrical shape from bacterial images obtained in TEM equipment at $20000 \times$ magnification (C. Zeiss EM902). Phytoplankton and ciliates were preserved in $1 \%$ acetic-lugol and counted under an inverted microscope at 1000 and 400× magnification, respectively. Zooplankton were preserved in $4 \%$ formaldehyde and counted under an inverted microscope at 100x magnification. Length or cell volume obtained by image analysis (Leica, Quantimet 500) was converted to carbon units according to length- or cell volume-weight relationships for phytoplankton (Rocha \& Duncan 1985), ciliates (Wetzel \& Likens 1991), rotifers (Ruttner-Kolisko 1977), and zooplankton (Botrell et al. 1976, Carrillo et al. 2001). No autotrophic picoplankton was found within $2 \mathrm{wk}$ after the sampling in whole or $1 \mu \mathrm{m}$ filtered lake water samples preserved with $1 \%$ (final conc.) formaldehyde-cacodylate buffer, after filtering them through black Nuclepore $0.2 \mu \mathrm{m}$ pore size filters and examining them by autofluorescence in an Leitz Fluovert FS epifluorescent microscope (Straskrabová et al. 1999).

Filtration methodology and justification. Composite water samples were taken from the depths described above, pre-screened through $40 \mu \mathrm{m}$ mesh to remove metazooplankton, and brought under cold and dark conditions to the laboratory within $3 \mathrm{~h}$ of collection for particulate content determinations. Serial filtration through precombusted $\left(1 \mathrm{~h}\right.$ at $\left.550^{\circ} \mathrm{C}\right) 1.0 \mu \mathrm{m}(\mathrm{GF} / \mathrm{B}$, Whatman) and $0.2 \mu \mathrm{m}$ (Anodisc, Whatman) pore size filters was then carried out $(\mathrm{Hg}<5 \mathrm{mmHg})$. After filtration, filters were dried $\left(24 \mathrm{~h}\right.$ at $\left.60^{\circ} \mathrm{C}\right)$ and kept desiccated until analysis.

We associated the 0.2 to $1.0 \mu \mathrm{m}$ size fraction with the free-living heterotrophic bacteria ('bacterial fraction'). The absence of autotrophic picoplankton in La Caldera and the predominance of coccus-type heterotrophic bacteria with a size ranging from 0.4 to $0.8 \mu \mathrm{m}$ in diameter indicate that contributions to this fraction from other organisms were negligible. As in Elser et al. (1995), a simple comparison between our experimental results for the $\mathrm{C}$ in the 0.2 to $1.0 \mu \mathrm{m}$ fraction and theoretical $\mathrm{C}$ estimations from bacterial C:P ratios already established in the literature (Fagerbakke et al. 1996) and assuming no $\mathrm{P}$ in detritus (Olsen et al. 1986) accounts for 8.2 to $52.0 \%$ (average $30.3 \%$ ) of the measured carbon.

Because of the absence of major size overlap between organisms in La Caldera, we interpreted the fraction between 1 and $40 \mu \mathrm{m}$ as autotrophic phytoplankton ('phytoplankton fraction'). Furthermore, the bacterial abundance in whole and $<1 \mu \mathrm{m}$ filtered water revealed that $>97 \%$ of the heterotrophic bacteria consistently passed through the $1.0 \mu \mathrm{m}$ pore size filter. Although protozoa could potentially form a part of our estimates for autotrophic phytoplankton, ciliate bio-

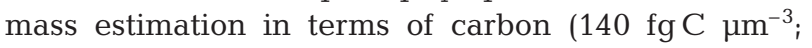
Wetzel \& Likens 1991) showed that the contribution of ciliates to this fraction was always under $4 \%$ (average $1.35 \%)$.

Chemical analyses. Bacterioplankton and phytoplankton samples for $\mathrm{C}$ and $\mathrm{N}$ determinations were analyzed using a Perkin-Elmer $2400 \mathrm{CNH}$. For the analysis of $\mathrm{P}$, filters were introduced into acid-washed vials and determined as soluble reactive phosphorus in $10 \mathrm{~cm}$ quartz cuvettes (acid molybdate technique) after digestion with a mixture of potassium persulfate and boric acid at $120^{\circ} \mathrm{C}$ for $30 \mathrm{~min}$. Samples for total phosphorus and total dissolved phosphorus were persulfate digested and analyzed as described above. Total nitrogen and total dissolved nitrogen samples were persulfate digested and measured as nitrate by means of the ultraviolet spectrophotometric screening method (APHA 1992). Blanks and standards were carried out for all procedures. All $\mathrm{C}: \mathrm{N}: \mathrm{P}$ ratios were calculated on a molar basis.

Spectrophotometric chl a determinations, corrected for phaeopigments, were made after filtration of 3 to $5 \mathrm{l}$ of $40 \mu \mathrm{m}$ screened lake water and a $24 \mathrm{~h}$ cold pigment extraction (Whatman GF/C) in $90 \%$ acetone (Jeffrey \& Humphrey 1975). 
Bacterioplankton and phytoplankton growth rates. Bacteria and phytoplankton growth rates $(\mu)$ were calculated from the abundance of in situ populations as shown in Eq. (1):

$$
\mu=\ln \left(N_{i+1} / N_{i}\right) / T
$$

where $N_{i}$ and $N_{i+1}$ are the abundance of bacteria and phytoplankton cells on 2 consecutive sample dates, and $T$ is the time (in days) between sample collections.

Measurements of bacterial and primary production. A total of 30 measurements of primary (PP) and bacterial production (BP) were made during the ice-free periods of 1996 and 1997. PP was measured with the ${ }^{14} \mathrm{C}$ method proposed by Steemann-Nielsen (1952). Sets of four $70 \mathrm{ml}$ quartz flasks (3 clear and 1 dark), with 10 $\mu \mathrm{Ci}$ of $\mathrm{NaH}^{14} \mathrm{CO}_{3}$ (SA: $8.4 \mathrm{Ci} \mathrm{mmol}{ }^{-1}$, NEN Dupont) added to each flask, were incubated in situ at $0.5 \mathrm{~m}$ under the surface of the lake, $0.5 \mathrm{~m}$ above the bottom, and at an intermediate depth for a $4 \mathrm{~h}$ period symmetrically distributed around noon. All flasks of each set were maintained horizontal during the incubation. PP was measured as total organic carbon by acidifying a $4 \mathrm{ml}$ subsample in a $20 \mathrm{ml}$ scintillation vial with $100 \mu \mathrm{l}$ of $1 \mathrm{~N} \mathrm{HCl}$, and allowing the vial to stand open in a hood for $24 \mathrm{~h}$ (no bubbling), as recommended by Lignell (1992). Particulate PP was determined by filtering an aliquot of $60 \mathrm{ml}$ through $1.0 \mu \mathrm{m}$ (particulate organic carbon $>1 \mu \mathrm{m}, \mathrm{POC}_{1}$ ) and $0.2 \mu \mathrm{m}$ (particulate organic carbon 0.2 to $1 \mu \mathrm{m}, \mathrm{POC}_{0.2}$ ) pore-size Nuclepore filters $25 \mathrm{~mm}$ in diameter (serial filtration). To minimize cell breakage, we applied minimal vacuum $(<100 \mathrm{~mm}$ of $\mathrm{Hg}$ ). The filters were placed in scintillation vials and the dissolved inorganic carbon $\left(\mathrm{DI}^{14} \mathrm{C}\right)$ was removed by adding $100 \mu \mathrm{l}$ of $1 \mathrm{~N} \mathrm{HCl}$. The filtrate $<0.2 \mu \mathrm{m}$ (dissolved organic carbon, DOC) was also collected and treated as described above for the PP. We added $16 \mathrm{ml}$ of liquid scintillation cocktail (Beckman Ready Safe) to the vials and radioactivity was counted after $12 \mathrm{~h}$ in a scintillation counter equipped with autocalibration (Beckman LS 6000 TA). The total $\mathrm{CO}_{2}$ in the lake water was calculated from measurements of the alkalinity and pH (APHA 1992). In all calculations, dark values were subtracted from corresponding light values.

The ${ }^{14} \mathrm{C}$ retained on the $0.2 \mu \mathrm{m}$ filters $\left(\mathrm{POC}_{0.2}\right.$ ) corresponds to the photosynthetic exudates assimilated by bacteria (PEA). However, because of respiration, PEA is underestimated by this procedure, and was therefore calculated assuming $40 \%$ respiration (Bell \& Sakshaug 1980):

$$
\mathrm{PEA}=\mathrm{POC}_{0.2}+(40 / 100) \times \mathrm{POC}_{0.2}
$$

Finally, the photosynthetic extracellular release (PER) was defined by:

$$
\mathrm{PER}=\mathrm{PEA}+\mathrm{DOC}
$$

BP was measured using bacterial incorporation of a precursor for DNA synthesis (Fuhrman \& Azam 1982); $25 \mathrm{ml}$ of lake water were added to ten acid-cleaned and sterilized flasks ( $6+4$ blanks), with $10.9 \mathrm{nM}$ (final conc.) [methyl- ${ }^{3} \mathrm{H}$ ] thymidine (SA: 76 to $82 \mathrm{Ci} \mathrm{mmol}^{-1}$, Amersham Pharmacia) added to each flask. This procedure provided a saturating $\left[{ }^{3} \mathrm{H}\right] \mathrm{TdR}$ concentration and a suitable incubation time (uptake of $\left[{ }^{3} \mathrm{H}\right] \mathrm{TdR}$ was linear over this period) for this system (Reche et al. 1996). Flasks were then incubated in situ for $1 \mathrm{~h}$ at $0.5 \mathrm{~m}$ under the surface, $0.5 \mathrm{~m}$ above the bottom, and at an intermediate depth. At the end of the incubation, $\mathrm{NaOH}$ was added (0.25 N, final conc.), causing ${ }^{3} \mathrm{H}$-labelled RNA base hydrolysis and stopping $\left[{ }^{3} \mathrm{H}\right] \mathrm{TdR}$ incorporation. $\mathrm{NaOH}$ was added $(0.25 \mathrm{~N}$, final conc.) to the blanks before the incubations. In the laboratory, the samples were treated with cold trichloroacetic acid (TCA) for $20 \mathrm{~min}$ (5\%, final conc.), leading to the precipitation of the DNA and proteins. The samples were filtered through $0.2 \mu \mathrm{m}$ pore size Nuclepore filters and rinsed twice with cold 5\% TCA. Half of the filters $(3+2$ blanks $)$ were then enzymatically digested with DNAse I (Boehringer Mannheim) solution ( $\mathrm{pH}=7.5)$, so that only macromolecules other than DNA remained in the filters. The $\left[{ }^{3} \mathrm{H}\right] \mathrm{TdR}$ incorporated into DNA was calculated as the difference between the 2 treatments (Torreton \& Bouvy 1991). The incorporated $\left[{ }^{3} \mathrm{H}\right] \mathrm{TdR}$ was converted to the number of cells produced by using the conversion factor of $1.07 \times 10^{18}$ cells mol ${ }^{-1}$ incorporated $\left[{ }^{3} \mathrm{H}\right] \mathrm{TdR}$ determined for this system (Carrillo et al. 2002). The amount of $\mathrm{C}$ produced was estimated by using the conversion factor $2 \times 10^{-14} \mathrm{~g} \mathrm{C} \mathrm{cell}^{-1}$ (Lee \& Fuhrman 1987).

Production bioassays. Two experiments were performed in late August (Day 239, when January 1 = Day 1) and early October (Day 282) 1997 in order to study the response of $\mathrm{PP}$ and $\mathrm{BP}$ to pulsed P. Composite water samples were passed through $40 \mu \mathrm{m}$ filters and distributed into 3 sets of triplicate $300 \mathrm{ml}$ Pyrex bottles. One set received $\mathrm{NaH}_{2} \mathrm{PO}_{4}$ to raise ambient $\mathrm{P}$ to a final dissolved N:P ratio of $16\left(\mathrm{~N}: \mathrm{P}_{16}\right)$. In the second set, $\mathrm{P}$ was added until a dissolved $\mathrm{N}: \mathrm{P}$ ratio of $5\left(\mathrm{~N}: \mathrm{P}_{5}\right)$ was reached. The final set acted as a control with no $\mathrm{P}$ enrichment $\left(\mathrm{N}: \mathrm{P}_{\mathrm{c}}\right)$. The amount of $\mathrm{P}$ required to accomplish the desired N:P ratios was calculated on the basis of the dissolved nutrient concentrations found in the water column on the previous sample date. In contrast to the routine PP measurements, only one incubation depth was set at $50 \%$ PAR light ( $5 \mathrm{~m})$. Incubation time and laboratory procedures remained unchanged.

Estimates of phytoplankton and bacterioplankton biomass were used to normalize PP and BP to specific productivity. In an attempt to distinguish whether inorganic $\mathrm{P}$ or algal carbon exudates could limit bacterioplankton 
growth and determine the relationship between phytoplankton and bacteria we compared PEA with bacterial growth requirements (BGR). BGR were estimated as the ratio of BP to bacterial growth efficiency (BGE), assuming a BGE of $9 \%$ as characteristic of oligotrophic waters (Biddanda et al. 2001) and of $30 \%$ for comparative purposes (Kristiansen et al. 1992).

Climatic data. Estimates of wet deposition fluxes of inorganic $\mathrm{P}$ were made using daily wet atmospheric depositions provided by Cetursa S.A. (Spain) and measurements of the dissolved inorganic content of the lake water. Values of daily atmospheric precipitation for the 3 years of the study period were gathered from measurements at 6 meteorological stations, approximately $3 \mathrm{~km}$ from the study lake and near the top of the mountains (maximum altitude $3482 \mathrm{~m}$ ). As described in Villar-Argaiz et al. (2001), P loading through atmospheric deposition was inferred as the difference in total dissolved phosphorus in the water column between the sample dates before and after a rainfall event.

Statistical analysis. The relationship between specific productivity and N:P ratio for phytoplankton and bacteria was analyzed by linear regression models computed using quasi-Newton iterations. The effect of P-enrichment on bacterial and phytoplankton specific productivity was assessed via 1-way ANOVA. Residuals of ANOVAs were examined to ensure they met model assumptions. Post-hoc comparisons between enriched and control treatments were tested by Tukey-test. In addition, differences between PER and BGR for each treatment were tested by Tukey-tests. Statistical analyses were performed with Statistica 5.1 (StatSoft 97).

\section{RESULTS}

\section{Biotic characterization}

Changes in the precipitation regime between years resulted in sudden physical, chemical and biological changes that affected the trophic conditions of the lake (Table 1). After a severe drought from 1990 to 1995 (371 mm, annual precipitation in 1995), the maximum depth dropped to a historic minimum of $1.5 \mathrm{~m}$ in 1995, increasing the catchment area-to-lake ratio (Table 1) and the potential contribution of sediments to the lake nutrient budget through resuspension (Villar-Argaiz et al. 2001). The ice-free period lasted for 7 mo during this anomalous year. In addition total phosphorus increased in the water column (Table 1), as did phytoplankton richness and diversity (Medina-Sánchez et al. 1999). The diversification of the plankton community was reflected in the appearance of ciliates and heterotrophic nanoflagel- lates in the water column (Fig. 1). Likewise, dramatic shifts in crustacean zooplankton composition and biomass accompanied the drought of 1995 and, although Mixodiaptomus laciniatus still dominated zooplankton biomass, rotifers became extremely abundant, constituting up to $50 \%$ of total zooplankton biomass. As a consequence, the autotrophic: heterotrophic biomass ratio $(\mathrm{A}: \mathrm{H})$ was below 1 in 1995 (Fig. 2).

Plentiful rains in 1996 (1816 mm, mean annual precipitation) caused a massive input of water after icemelt and the lake returned to a maximum depth of $\sim 14 \mathrm{~m}$. During 1996, the lake underwent a reoligotrophication process in which the physical and chemical conditions of the water were drastically affected. For example, total phosphorus, as well as other mineral nutrients, were on average lower in 1996 than during the dry year of 1995 (Table 1). The recovery of the biotic community was more gradual and impaired for zooplankton, which were extremely scarce throughout the year (mean zooplankton abundance $\approx 1$ ind. $\mathrm{l}^{-1}$; Fig. 3). In contrast, algae and bacteria were among the first to take advantage of the absence of grazers in 1996. During 1996, the community was dominated by Chromulina nevadensis, and in spite of the reoligotrophication process of the lake and the cold water temperatures, the levels of chl a doubled those in 1995 (Table 1). Under these circumstances, a microbial food web with abundant phytoplankton prevailed and, with the scarcity of predators, ciliates were able to build up high population densities (Fig. 4). As a consequence, the A:H ratio was permanently $>1$ in 1996, especially after ice-out (Fig. 2).

As in 1996, abundant rains in 1997 (1755 mm) maintained the maximum lake depth within similar narrow limits. During this year, ciliates became very sparse and metazooplankton achieved densities of 20 to 30 ind. $\mathrm{l}^{-1}$ towards the middle of the season (Fig. 3), from which point the A:H ratio returned to values below 1 (Fig. 2).

\section{Contribution of the organisms to total particulate matter}

Table 2 shows the relative contributions of bacteria, phytoplankton and zooplankton fractions to the total pool of particulate organic matter. Bacterial $\mathrm{C}$ gained in importance as a fraction of total particulate carbon over the 3 years, whereas the contribution of $\mathrm{P}$ remained relatively stable and that of $\mathrm{N}$ decreased after 1995. Phytoplankton was the principal storage compartment for $\mathrm{N}$ and $\mathrm{P}$ during 1996, while $\mathrm{C}$ showed a decreasing pattern over the years. Zooplankton never contributed more than $10 \%$ to the total particu- 
Table 1. Summary of several physical, chemical and biological characteristics of Lake La Caldera, Spain, during the 3 years of the study. Values are means for the water profile; range in parentheses. TN: total nitrogen; TP: total phosphorus

\begin{tabular}{|c|c|c|c|c|c|c|}
\hline Month & $\begin{array}{l}\text { Max. depth } \\
\text { (m) }\end{array}$ & $\begin{array}{c}\text { Depth } 25 \% \\
\text { surface light (m) }\end{array}$ & $\begin{array}{l}\text { Temp. } \\
\left({ }^{\circ} \mathrm{C}\right)\end{array}$ & $\begin{array}{c}\mathrm{TN} \\
\left(\mu \mathrm{g} \mathrm{N}^{-1}\right)\end{array}$ & $\begin{array}{c}\text { TP } \\
\left(\mu g \mathrm{P}^{-1}\right)\end{array}$ & $\begin{array}{c}\text { Chl a } \\
\left(\mu g \mathrm{l}^{-1}\right)\end{array}$ \\
\hline \multicolumn{7}{|l|}{1995} \\
\hline May & 2.1 & 1.9 & 12.0 & $\begin{array}{c}426 \\
(324-571)\end{array}$ & $\begin{array}{c}6.7 \\
(4.6-9.6)\end{array}$ & $\begin{array}{c}1.6 \\
(0.2-4.3)\end{array}$ \\
\hline Jun & 1.8 & 1.9 & 12.5 & $\begin{array}{c}311 \\
(253-386)\end{array}$ & $\begin{array}{c}4.9 \\
(4.2-5.5)\end{array}$ & $\begin{array}{c}0.3 \\
(0.1-0.5)\end{array}$ \\
\hline Jul & 1.7 & 1.5 & 15.4 & $\begin{array}{c}329 \\
(269-380)\end{array}$ & $\begin{array}{c}5.9 \\
(4.7-7.8)\end{array}$ & $\begin{array}{c}0.1 \\
(0.1-0.2)\end{array}$ \\
\hline Aug & 1.6 & 1.1 & 14.0 & $\begin{array}{c}575 \\
(387-842)\end{array}$ & $\begin{array}{c}9.9 \\
(6.9-13.2)\end{array}$ & $\begin{array}{c}0.7 \\
(0.1-1.5)\end{array}$ \\
\hline Sep & 1.6 & 0.8 & 7.5 & $\begin{array}{c}620 \\
(589-682)\end{array}$ & $\begin{array}{c}12.7 \\
(10.1-16.3)\end{array}$ & $\begin{array}{c}0.8 \\
(0.2-1.4)\end{array}$ \\
\hline Oct & 1.5 & 0.7 & 6.9 & $\begin{array}{c}666 \\
(563-943)\end{array}$ & $\begin{array}{c}5.2 \\
(2.5-6.6)\end{array}$ & $\begin{array}{c}0.3 \\
(0.2-0.3)\end{array}$ \\
\hline Nov & 1.5 & 0.5 & 4.2 & 612 & $\begin{array}{l}2.3 \\
-\end{array}$ & $\begin{array}{c}0.3 \\
-\end{array}$ \\
\hline $\begin{array}{l}\text { Annual } \\
\text { average }\end{array}$ & 1.7 & 1.3 & 11.4 & $\begin{array}{c}477 \\
(253-943)\end{array}$ & $\begin{array}{c}7.1 \\
(2.3-16.3)\end{array}$ & $\begin{array}{c}0.6 \\
(0.1-4.3)\end{array}$ \\
\hline \multicolumn{7}{|l|}{1996} \\
\hline Jul & 14.4 & 4.0 & 1.6 & $\begin{array}{c}617 \\
(479-865)\end{array}$ & $\begin{array}{c}4.6 \\
(3.6-5.2)\end{array}$ & $\begin{array}{c}0.9 \\
(0.1-2.1)\end{array}$ \\
\hline Aug & 13.3 & 8.3 & 6.5 & $\begin{array}{c}480 \\
(441-525)\end{array}$ & $\begin{array}{c}5.4 \\
(4.5-6.3)\end{array}$ & $\begin{array}{c}1.5 \\
(1.0-2.2)\end{array}$ \\
\hline Sep & 12.7 & 6.0 & 7.7 & $\begin{array}{c}457 \\
(436-505)\end{array}$ & $\begin{array}{c}11.4 \\
(3.9-32.1)\end{array}$ & $\begin{array}{c}2.3 \\
(1.5-2.9)\end{array}$ \\
\hline Oct & 11.8 & 9.0 & 6.0 & $\begin{array}{c}383 \\
(375-391)\end{array}$ & $\begin{array}{c}3.6 \\
(3.3-3.9)\end{array}$ & $\begin{array}{c}0.59 \\
(0.57-0.60)\end{array}$ \\
\hline $\begin{array}{l}\text { Annual } \\
\text { average }\end{array}$ & 13.3 & 6.7 & 5.2 & $\begin{array}{c}505 \\
(375-865)\end{array}$ & $\begin{array}{c}4.7 \\
(3.3-6.3)\end{array}$ & $\begin{array}{c}1.4 \\
(0.1-2.9)\end{array}$ \\
\hline \multicolumn{7}{|l|}{1997} \\
\hline Jun & 14.1 & 7.0 & 1.2 & $\begin{array}{c}309 \\
(265-353)\end{array}$ & $\begin{array}{c}1.9 \\
(1.4-2.5)\end{array}$ & $\begin{array}{c}0.4 \\
(0.3-0.5)\end{array}$ \\
\hline Jul & 13.1 & 8.2 & 5.5 & $\begin{array}{c}325 \\
(259-477)\end{array}$ & $\begin{array}{c}4.2 \\
(3.4-5.2)\end{array}$ & $\begin{array}{c}0.8 \\
(0.5-1.1)\end{array}$ \\
\hline Aug & 12.2 & 7.7 & 11.5 & $\begin{array}{c}362 \\
(281-464)\end{array}$ & $\begin{array}{c}6.5 \\
(5.2-7.4)\end{array}$ & $\begin{array}{c}0.6 \\
(0.4-0.8)\end{array}$ \\
\hline Sep & 11.2 & 7.0 & 11.6 & $\begin{array}{c}234 \\
(198-294)\end{array}$ & $\begin{array}{c}3.8 \\
(3.3-4.5)\end{array}$ & $\begin{array}{c}0.3 \\
(0.2-0.4)\end{array}$ \\
\hline Oct & 11.0 & - & 7.7 & $\begin{array}{c}285 \\
(175-393)\end{array}$ & $\begin{array}{c}4.1 \\
(3.0-4.8)\end{array}$ & $\begin{array}{c}0.2 \\
(0.1-0.2)\end{array}$ \\
\hline $\begin{array}{l}\text { Annual } \\
\text { average }\end{array}$ & 11.9 & 7.6 & 7.4 & $\begin{array}{c}309 \\
(175-477)\end{array}$ & $\begin{array}{c}4.4 \\
(1.4-7.4)\end{array}$ & $\begin{array}{c}0.5 \\
(0.1-1.1)\end{array}$ \\
\hline
\end{tabular}

late matter of any given element, with large interannual fluctuations (Table 2).

Atmospheric depositions associated with rainfall events usually generated a significant increase of total dissolved phosphorus in lake water (see arrows in Fig. 5), a substantial fraction of which was incorporated into particulate fractions by organisms. However, the extent to which this 'new' $\mathrm{P}$ was used or stored was not the same for bacteria and phytoplankton. Thus, phytoplankton-P increased by 526\% (from 0.11 to $0.55 \mu \mathrm{M} \mathrm{P}$ ), nearly triple the $186 \%$ increase in bacteria (from 0.09 to $0.18 \mu \mathrm{M}$ P) after external load- ing of over $0.8 \mu \mathrm{M}$ P on Day 246 in 1996 (Fig. 5). As a consequence, the phytoplankton fraction reached $7 \% \mathrm{P}$ as dry weight (data not shown). Smaller atmospheric inputs in 1997 (e.g. Day 239) resulted in phytoplankton $\mathrm{P}$ increases of $66 \%$ (from 0.011 to $0.19 \mu \mathrm{M} \mathrm{P}$ ) and bacteria increases of $\sim 30 \%$ (from 0.09 to $0.11 \mu \mathrm{M}$ P). Overall, a high proportion (63 to $79 \%$ ) of the phosphorus derived from atmospheric inputs and dissolved in lake water was incorporated by both bacterial and phytoplankton fractions, although between 2 and 4 times more efficiently in the latter fraction. 


\section{Elemental ratios and natural bacterioplankton and phytoplankton dynamics}

Bacterioplankton and phytoplankton N:P ratios were high and did not follow any trend during 1995 (Figs. 3 \& 4). In contrast, they exhibited strong seasonal variations during the more oligotrophic wet years, with low values following ice-out that increased towards summer and drastically decreased after wet depositions in the lake area. Although there was no relationship between bacterial N:P ratio and bacterial growth (insets in Fig. 4) in any of the studied years, bacteria abundance increased in parallel to bacteria N:P ratio for at least the first half of the ice-free period in 1996 and 1997. Bacteria populations sharply decreased concurrently with the development of ciliates (after Days 221 to 229 in 1995 and after Day 246 in 1996). Likewise, no relationships between phytoplankton N:P and phytoplankton
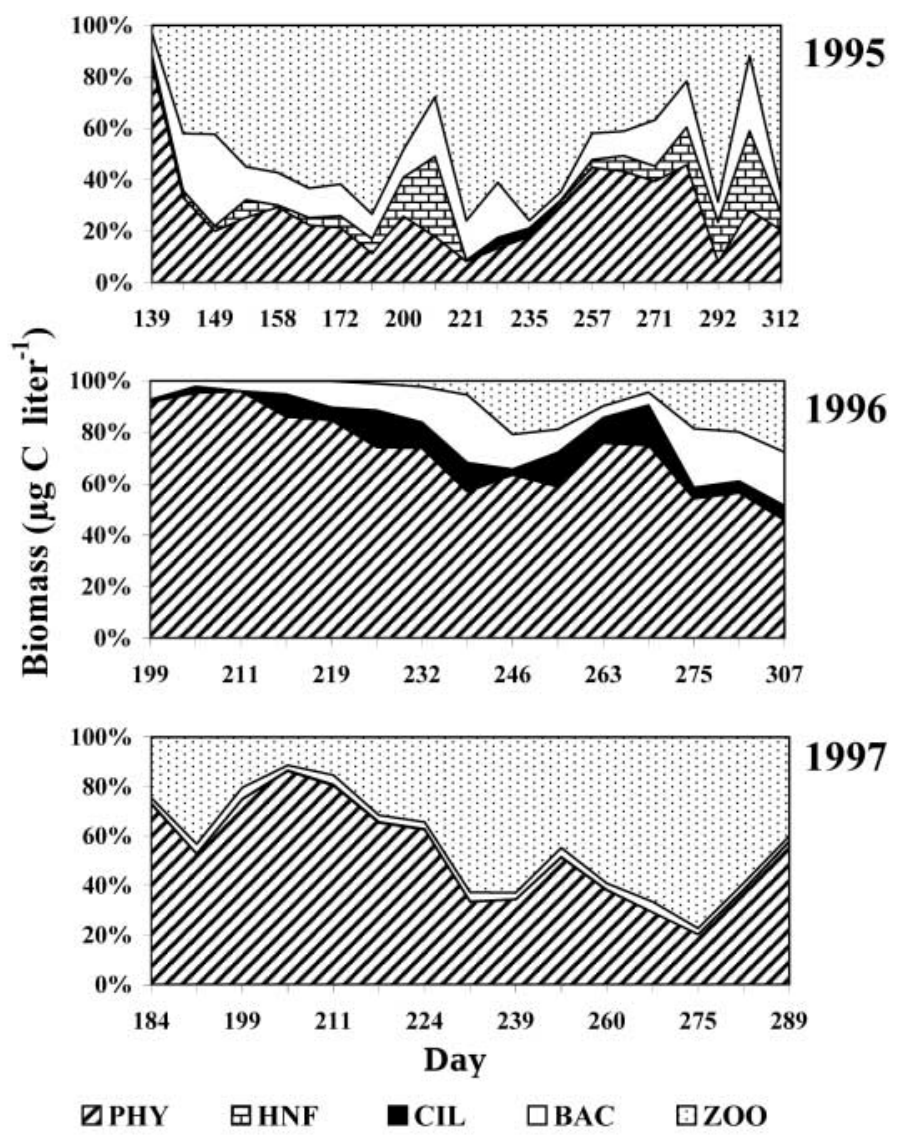

1997

Fig. 1. Annual shifts of food web compartments in Lake La Caldera, Spain. PHY, phytoplankton; HNF, heterotrophic nanoflagellates; CIL, ciliates; BAC, heterotrophic bacteria; ZOO, metazooplankton. All biomasses are estimated from organism abundance and length- or cell volume-conversions to dry weight, and recommended conversions to carbon units (see 'Materials and methods')

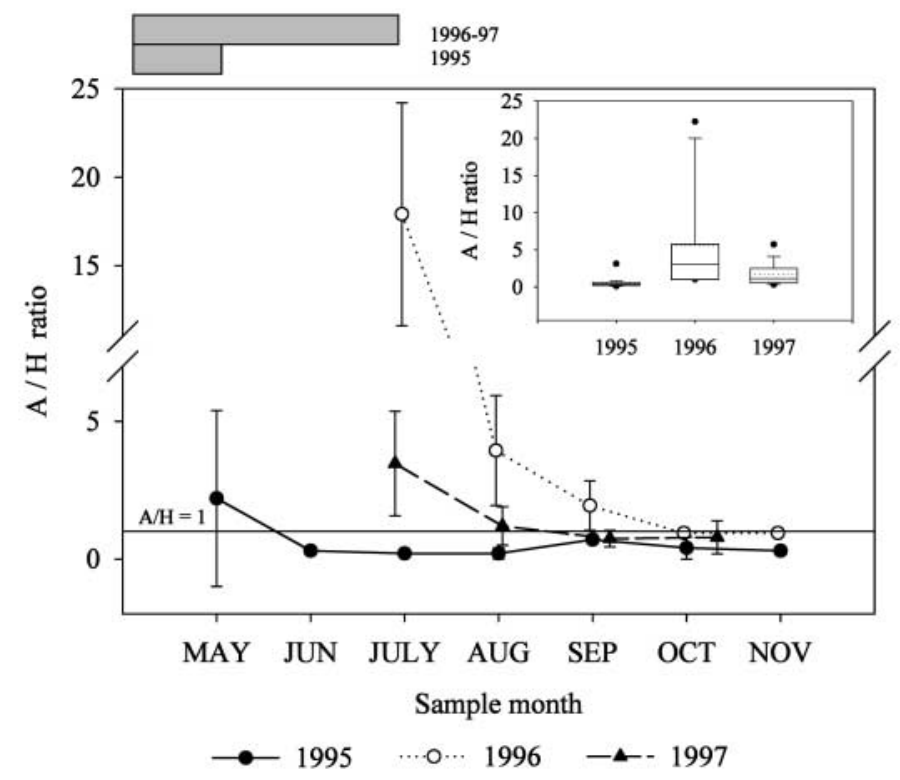

Fig. 2. Temporal dynamics of the autotrophic/heterotrophic biomass ratio [autotrophs/(bacteria + ciliates + zooplankton)] for the 3 years of the study period. Values are monthly means \pm 1 SD. Grey horizontal bars on graph indicate time at ice-out in 1995 and 1996-97. Inset corresponds to the mean annual median (central line of box), mean (dotted line of box) and variability (25 and $75 \%$ quartiles, box; 5 and $95 \%$ percentiles, whiskers) in autotrophic: heterotrophic biomass ratio (A:H ratio)

abundance were found in 1995 and 1997 (Fig. 3), when a large zooplankton population dominated the lake food web. However, abundance of phytoplankton increased in 1996, when N:P ratios were generally under 22. This dynamic was illustrated by the increase in phytoplankton growth rate with the decrease in N:P ratio (middle inset in Fig. 3). This figure shows that the outlier (indicated by arrow) corresponds to the date when a large atmospheric load into the lake area was observed (Days 246 to 254). Thus, high algal growth on this date coincided with maximum P content, lowering the phytoplankton $\mathrm{N}: \mathrm{P}$ ratio to a seasonal minimum of $\sim 5$ on Day 254.

\section{Elemental ratios and specific productivity of the organisms}

$\mathrm{POC}_{1}$ showed small interannual but large intraannual differences, varying from 0.17 to $0.53 \mu \mathrm{g} \mathrm{Cl}^{-1} \mathrm{~h}^{-1}$ (mean values for the water column) in 1996, and from 0.11 to $0.59 \mathrm{\mu g} \mathrm{C}^{-1} \mathrm{~h}^{-1}$ in 1997 . The BP was 2 orders of magnitude lower than $\mathrm{POC}_{1}$ values. BP was very constant during 1996 (mean values for the water column; 0.003 to $0.006 \mu \mathrm{g} \mathrm{C} \mathrm{l}^{-1} \mathrm{~h}^{-1}$ ) but varied from 0.003 to $0.013 \mu \mathrm{g} \mathrm{Cl}^{-1} \mathrm{~h}^{-1}$ in 1997. 
Fig. 6 summarizes the relationship between N:P ratio and specific productivity $\left(\mu \mathrm{g} C \mu \mathrm{g} \mathrm{C}^{-1} \mathrm{~d}^{-1}\right)$ for phytoplankton found in 1996 and 1997. Regressions were significant and the negative slopes were statistically different between these years ( $\mathrm{p}<0.01, F-$ test), with a steeper slope in 1996. These results predict a greater specific productivity at low N:P ratios. In contrast, bacteria did not exhibit this relationship (Fig. 6).

\section{Short-term response to a nutrient pulse}

Two experiments were performed in 1997 in order to assess the response of phytoplankton and bacterial productivity to a $\mathrm{P}$ pulse at distinct substrate $\mathrm{N}: \mathrm{P}$ ratios. Supplementation with $\mathrm{P}$ resulted in significant increases in PP relative to controls (ANOVA, $F_{2,6}=$ 26.1, $\mathrm{p}=0.001$ in August $F_{2,6}=111.3, \mathrm{p}<0.001$ in October) with the exception of the $\mathrm{N}: \mathrm{P}_{16}$ treatment in the October experiment, when the $\mathrm{N}: \mathrm{P}$ ratio of the substrate initially exceeded that of the algae (Fig. 7). For bacterioplankton, the negative effect of P amendment with respect to controls in August (ANOVA, $\left.F_{2,6}=7.2, \mathrm{p}=0.025\right)$ contrasted with the strong positive effect of increasing amounts of $\mathrm{P}$ on bacterial productivity in October (ANOVA, $F_{2,6}=23.2, \mathrm{p}=$ 0.002; Fig. 7). PER drastically decreased during the enriched treatments in August and was significantly lower (Tukey-test, $\mathrm{p}=0.029, \mathrm{BGR}_{0.09}$ for $\mathrm{N}: \mathrm{P}_{16}$ ) or of the same magnitude (Tukey-tests, $\mathrm{p}>0.05$, both BGR for $\mathrm{N}: \mathrm{P}_{c}$ and $\mathrm{N}: \mathrm{P}_{5}$, and $\mathrm{BGR}_{0.3}$ for $\mathrm{N}: \mathrm{P}_{16}$ ) as carbon requirements for bacteria. However, the inverse

Table 2. Relative contribution (in \%) of bacteria, phytoplankton and zooplankton fractions to total particulate organic matter for the 3 years of the study. Element contribution to bacterial and phytoplankton fractions were experimentally obtained by serial filtration in this study. Data for zooplankton from Villar-Argaiz et al. (2001)

\begin{tabular}{|cccc|}
\hline Year & $\begin{array}{c}\text { Bacteria } \\
\text { fraction } \\
(0.2-1.0 \mu \mathrm{m})\end{array}$ & $\begin{array}{c}\text { Phytoplankton } \\
\text { fraction } \\
(1-40 \mu \mathrm{m})\end{array}$ & $\begin{array}{c}\text { Zooplankton } \\
\text { fraction } \\
(>40 \mu \mathrm{m})\end{array}$ \\
\hline $\mathbf{\%} \mathbf{C}$ & & & \\
1995 & $51.8 \pm 13.6$ & $46.1 \pm 13.2$ & $2.1 \pm 1.2$ \\
1996 & $58.1 \pm 15.6$ & $39.7 \pm 14.3$ & $2.2 \pm 3.4$ \\
1997 & $66.6 \pm 11.9$ & $28.7 \pm 12.9$ & $4.7 \pm 2.3$ \\
$\mathbf{\%} \mathbf{N}$ & & & \\
1995 & $56.3 \pm 12.7$ & $39.5 \pm 12.6$ & $4.2 \pm 3.9$ \\
1996 & $32.0 \pm 12.3$ & $65.4 \pm 13.3$ & $2.6 \pm 3.5$ \\
1997 & $35.2 \pm 26.9$ & $56.3 \pm 26.3$ & $8.5 \pm 4.3$ \\
$\mathbf{\%} \mathbf{P}$ & & & \\
1995 & $41.7 \pm 14.4$ & $51.5 \pm 16.9$ & $6.8 \pm 6.2$ \\
1996 & $36.8 \pm 7.2$ & $60.8 \pm 7.8$ & $2.4 \pm 3.2$ \\
1997 & $42.0 \pm 11.0$ & $48.9 \pm 12.9$ & $9.0 \pm 6.1$ \\
\hline
\end{tabular}
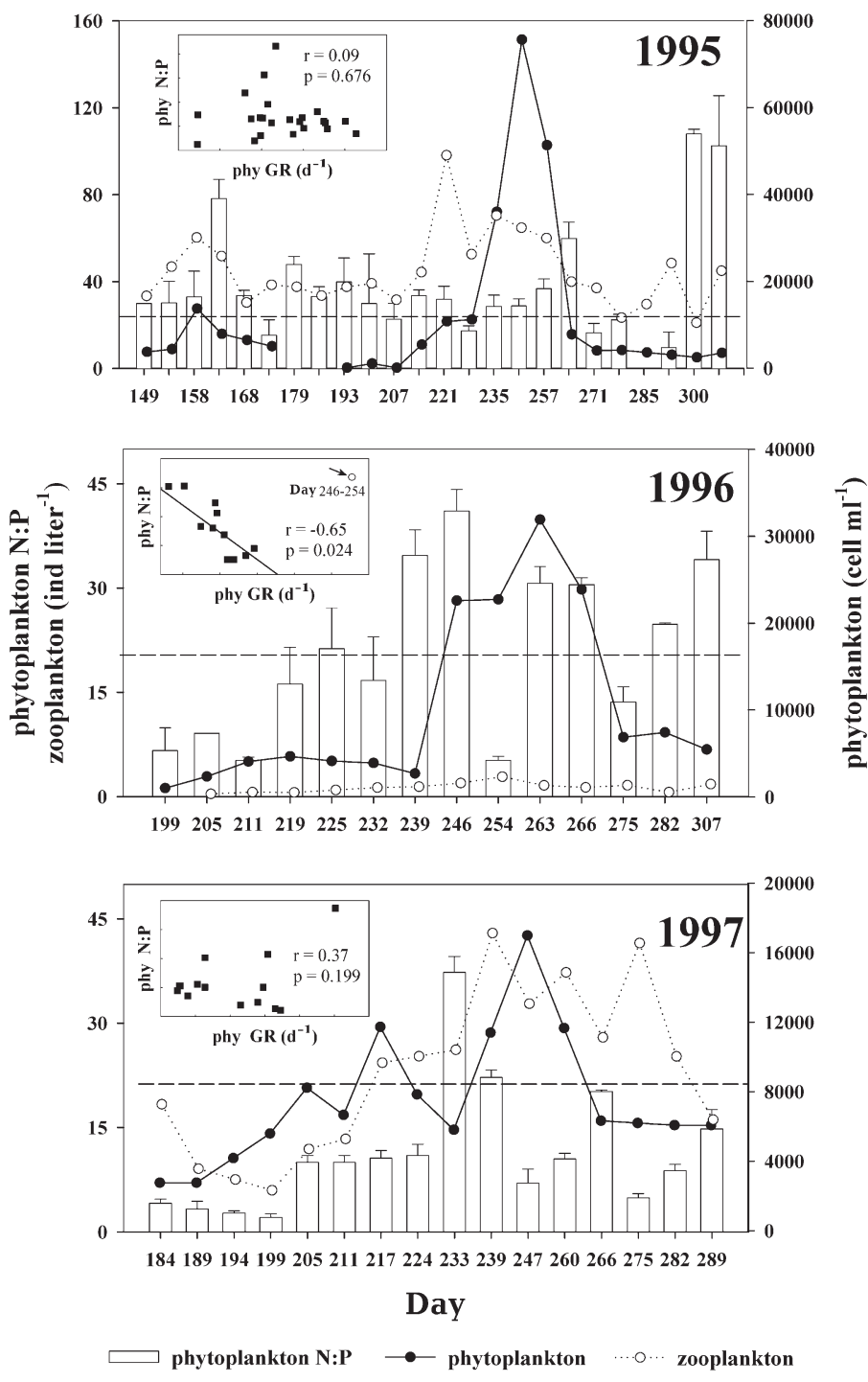

Fig. 3. Temporal distribution of phytoplankton (filled circles) and zooplankton abundance (open circles) and phytoplankton $\mathrm{N}$ :P ratio (open bars) in La Caldera. Organism abundances are means for the water column. Phytoplankton N:P ratios below the dashed lines are considered to be not P limited (threshold values according to Healey \& Hendzel 1980); error bars indicate standard deviation from triplicate samples. Insets represent the relationship between $\mathrm{N}$ :P ratio (phy N:P) and growth rate (phy GR) for phytoplankton. Sample indicated with an arrow in the middle inset was associated with a major deposition event and was not included in the regression analysis

trend was observed for the October experiment, which recorded a slight increase in PER for the $\mathrm{N}: \mathrm{P}_{16}$ treatment and an over 6-fold increase for the $\mathrm{N}: \mathrm{P}_{5}$ treatment, with respect to controls (Fig. 8). In this experiment, carbon excretion by algae amply exceeded BGR for both BGEs in all treatments (Tukey-tests, $\mathrm{p}<0.01, \mathrm{~N}: \mathrm{P}_{\text {ci }} \mathrm{p}<0.001, \mathrm{~N}: \mathrm{P}_{16}$ and $\left.\mathrm{N}: \mathrm{P}_{5}\right)$. 


\section{DISCUSSION}

\section{Changes in trophic food web}

The drought produced a reduction in the total volume of the lake, which not only increased sediment release in the water column but also induced additional stress due to overcrowding of crustacean zooplankton (Villar-Argaiz et al. 2001). It is now recognized that the net effect of sediment resuspension is important in oligotrophic lakes because it
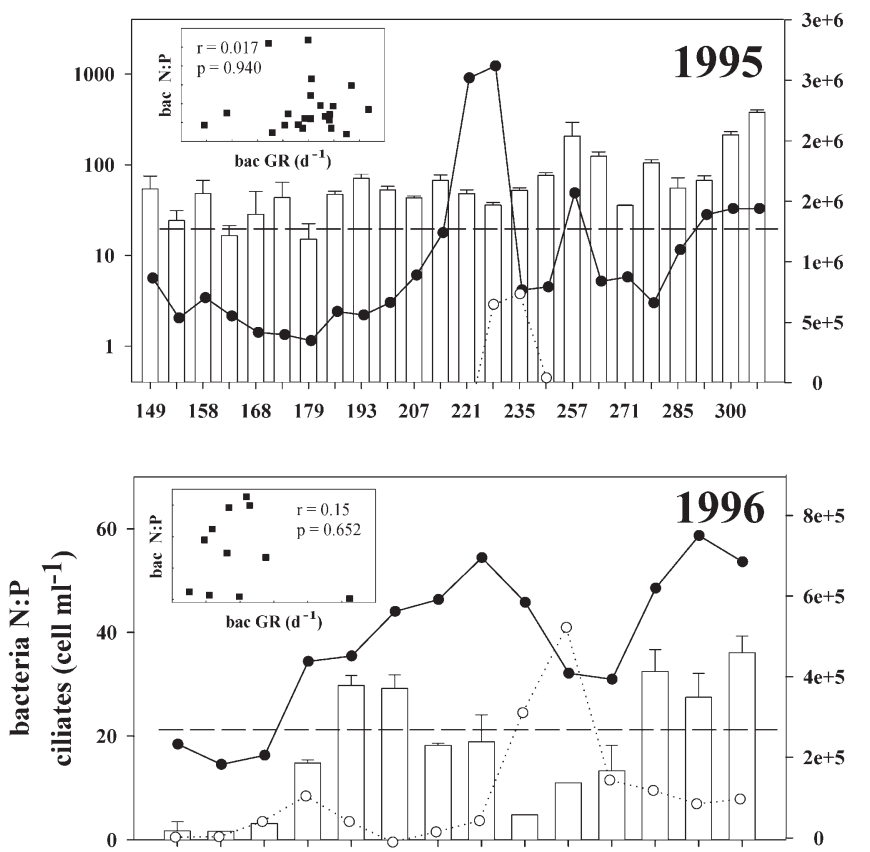

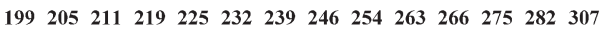

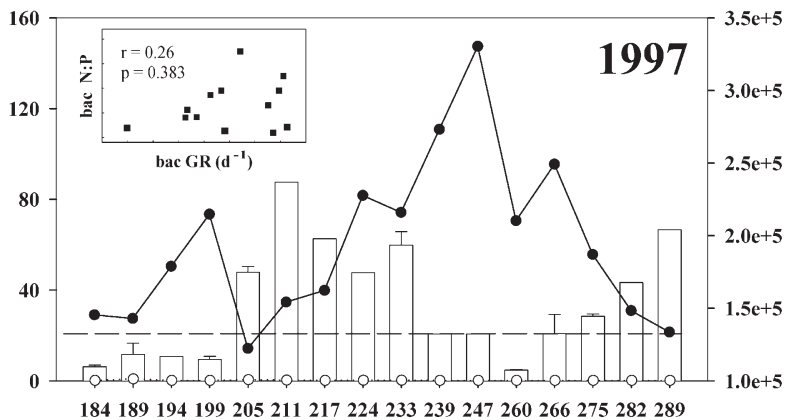

Day

\section{$\square$ bacteria $\mathrm{N}: \mathrm{P}$ ratio \\ ..... Ciliates \\ $\longrightarrow$ Bacteria}

Fig. 4. Temporal distribution of bacterial (filled circles) and ciliate abundance (open circles) and bacteria N:P ratio (open bars) in La Caldera. Abundances are means for the water column $\pm 1 \mathrm{SD}$. Error bars in open bars indicate standard deviation from triplicate samples. Insets represent the relationship between N:P ratio (bac N:P) and growth rate (bac GR) for bacteria. Note the log scale on the left axis of upper panel
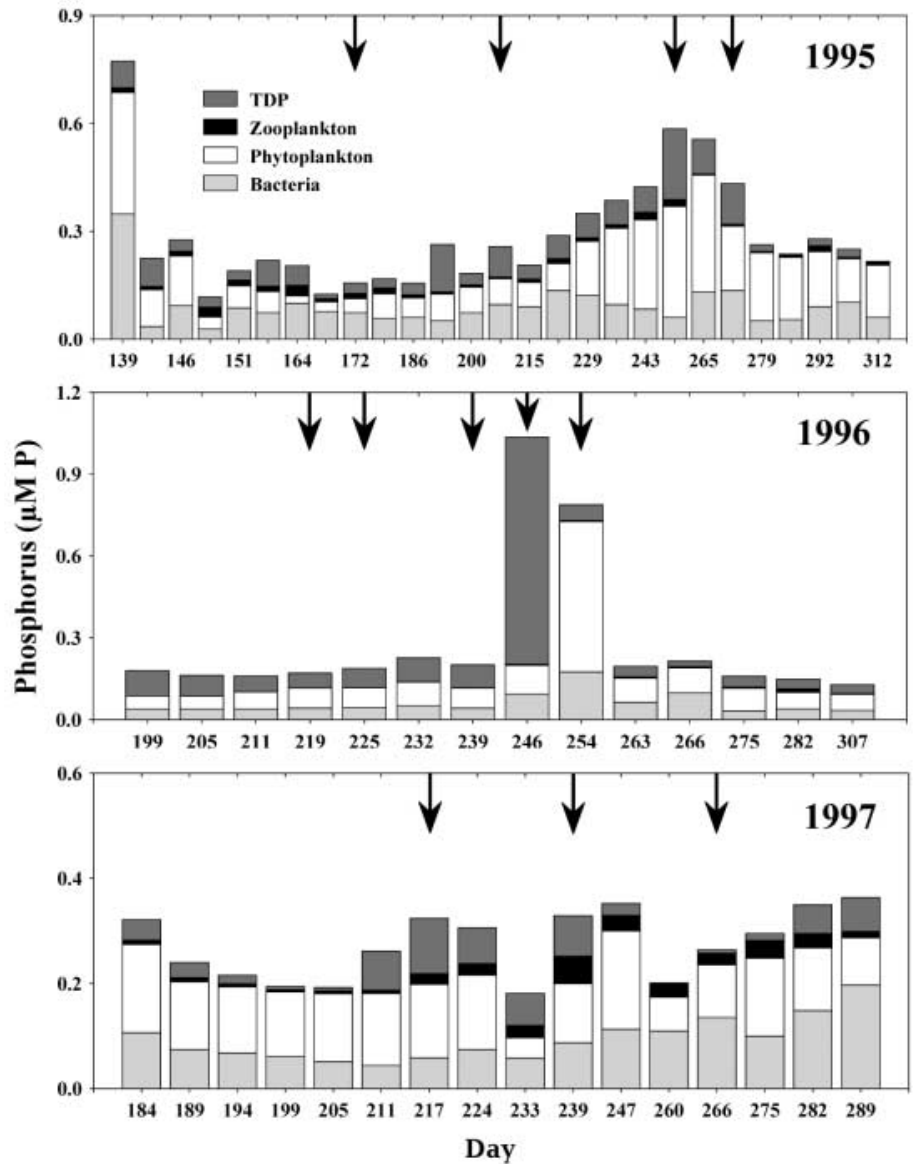

Fig. 5. Temporal distribution of phosphorus in particulate (bacteria, phytoplankton and zooplankton) and dissolved (TDP) fractions during the study period. Rainfalls in the lake area are indicated by arrows

enhances the interannual variability of lake trophic status and the uncoupling of autotrophic and heterotrophic processes (Cotner et al. 2000). In addition, there is evidence that the annual shifts in the importance of a classical or microbial food web should be more apparent in systems susceptible to environmental stress (Porter 1996), including intense droughts with major effects on the hydraulic load of the lake. Thus, the interannual patterns in the ratio of total autotrophic to heterotrophic biomass observed in this study provide a good measure of changes in food web structure, suggesting a systematic shift from a complex food web with a well-developed grazing and microbial food web in 1995 to a microbial-dominated food web, where protists were especially important, in 1996. Ciliates and heterotrophic nanoflagellates, organisms rarely found in the lake before this study (Echevarría et al. 1990, Carrillo et al. 1995), were common during 1995 and 1996. In contrast, larger zooplankton became very scarce in 1996 after the 
massive input of water associated with snow and ice melt. The return to normal zooplankton densities for this lake (Carrillo et al. 1995) did not occur until the mid-ice-free season (August) of 1997, probably due to the low growth rates of the dominant calanoid copepod (Carrillo et al. 2001) and the low water temperatures of the lake during the wet years $(1996,1997)$. In August 1997 the A:H ratio dropped below 1, accounting for the well-documented high herbivore versus autotroph biomass in oligotrophic waters (Gasol et al. 1997), and a classical grazing food web was reestablished.
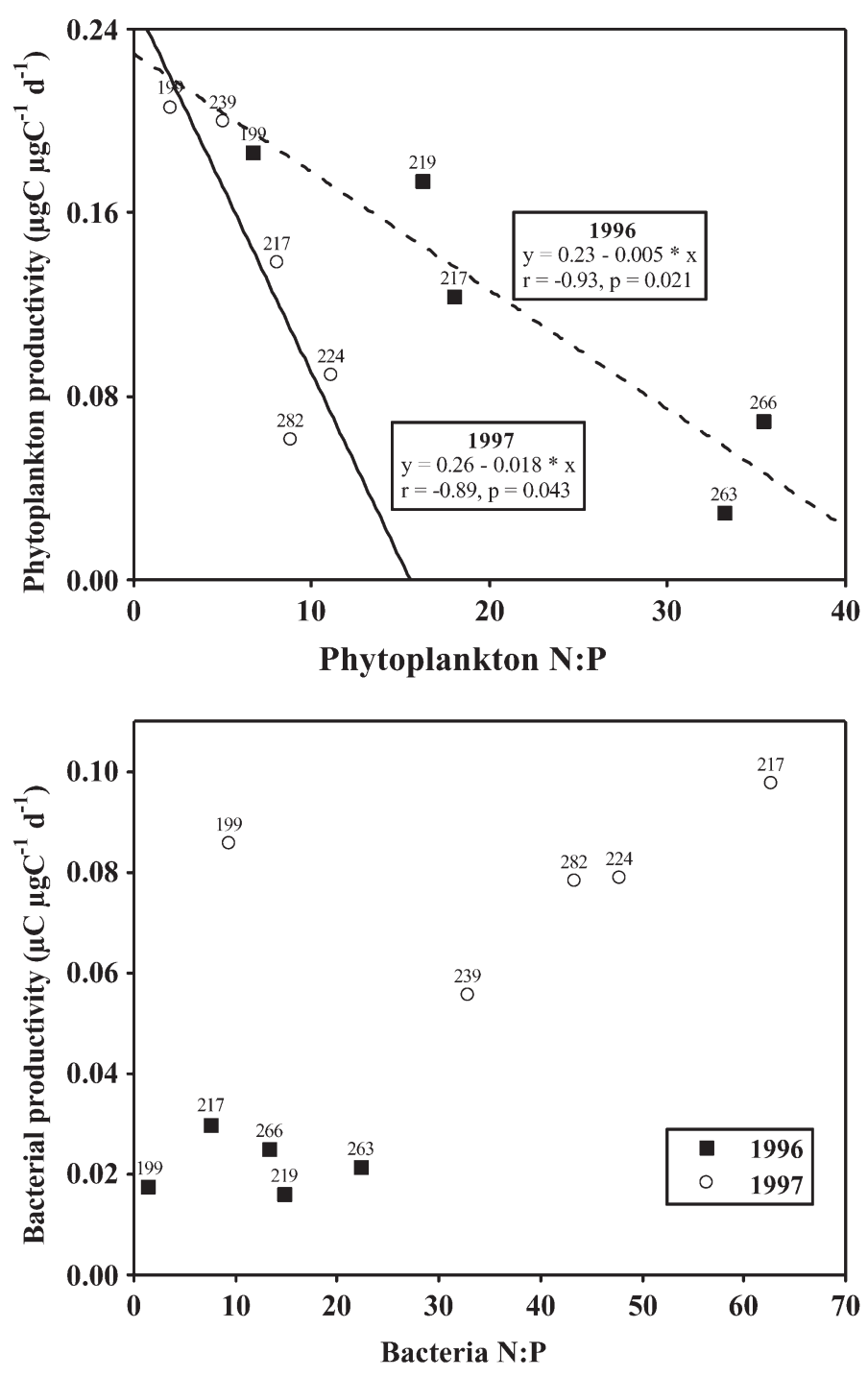

Fig. 6. Relationships between biomass-normalized $\mathrm{POC}_{1}$ and phytoplankton N:P (upper panel) and between biomassnormalized BP and bacteria N:P (lower panel) in 1996 and 1997. Specific production values for phytoplankton and bacterioplankton are means of 3 depths each consisting of 3 replicates. Number on each data point represents the sampling day

\section{Phytoplankton and bacteria elemental composition and growth}

Our measurements of $\mathrm{N}: \mathrm{P}$ ratios in phytoplankton and bacterial fractions were consistent with values found in other oligotrophic lakes using similar methods (Elser et al. 1995, Kreeger et al. 1997), although they were slightly higher during the atypical year of the drought. According to the criteria of Healey \& Hendzel (1980), the algae were severely P-deficient (N:P > 22) in 1995, August 1996 and early September of 1996 (Days 219 to 246) and generally not P-limited in 1997. Following the threshold proposed by Chrzanowski et al. (1996), bacteria grew at low rates (N:P > 20 to 24) in 1995 and in August (Days 211 to 233) and October (Day 275 onwards) of the wet years. As a general pattern, both bacteria and algae showed low N:P ratios following ice-out and external deposition events during the wet years, emphasizing the importance of ice-out and atmospheric processes as $\mathrm{P}$ sources for plankton communities.

To estimate whether the growth of bacteria and phytoplankton were linked to their stoichiometric composition, as has been proposed, we compared N:P ratios of both fractions to their growth rate, measured by following changes in the abundance of organisms between 2 successive sampling dates. Our results indicate that the complexity of natural communities and/or the impact of predators may lead to inaccurate assessments of growth rates and, therefore, to misleading relationships with elemental stoichiometry. This would explain why phytoplankton N:P was related to its growth rate only when predators were scarce in 1996 (middle inset in Fig. 3). Conversely, specific productivity provided instantaneous measurements of phytoplankton turnover rates that related well to the phytoplankton N:P ratio (Fig. 6). However, these relationships exhibited different slopes for 1996 and 1997. The finding that phytoplankton N:P ratios were generally higher in 1996 than in 1997 and were related to total abundance of zooplankton for both years (Fig. 9) suggests that grazing pressure (very low in 1996 with mean zooplankton abundance $<1$ ind. $\mathrm{l}^{-1}$ ) may alter phytoplankton capacity to store $\mathrm{P}$ relative to $\mathrm{C}$ or $\mathrm{N}$. This effect has already been proposed for seston (Hessen \& Andersen 1992). We observed that algae with little predator pressure could grow to show indices of $\mathrm{P}$ deficiency $(\mathrm{N}: \mathrm{P}>22)$ in 1996. However, and according to stoichiometric principles, the decreasing ontogenetic demands for $\mathrm{P}$ of a growing copepod population in 1997 would provide an excess of recycled $\mathrm{P}$ relative to $\mathrm{N}$. This could alleviate phytoplankton limitation for this element (Villar-Argaiz et al. 2002) and contribute to maintaining phytoplankton $\mathrm{N}$ :P ratio within a narrow range, lower than that of 
AUGUST
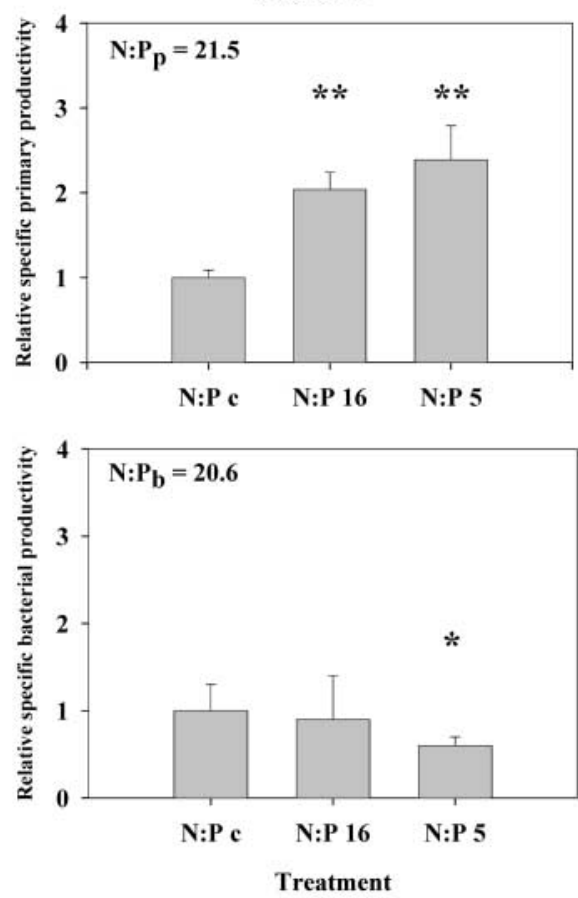

Fig. 7. Biomass-normalized values of primary and bacterial production for each nutrient treatment divided by the respective control mean for August and October experiments (relative specific PP and relative specific BP, respectively). Values are given for 3 replicates and error bars represent \pm 1 SD. A response larger than 1 was interpreted as stimulating bacterial or phytoplankton production and a response less than 1 implied inhibition of production. $\mathrm{N}: \mathrm{P}_{\mathrm{p}}$ and $\mathrm{N}: \mathrm{P}_{\mathrm{b}}$ represent the N:P ratios for phytoplankton and bacterial fractions at the start of the incubations, respectively. Post-hoc comparisons between enriched and control treatments were tested by Tukey-tests and significance adjusted according to the Bonferroni test. ${ }^{*} \mathrm{p}<0.05 ;{ }^{* *} \mathrm{p}<0.01 i^{* * *} \mathrm{p}<0.001$

1996. These arguments support previous findings that the intensity of grazing-recycling processes constitutes an important regulator of the phytoplankton N:P ratio (Carrillo et al. 1996, Villar-Argaiz et al. 2001).

On the other hand, bacteria N:P did not correlate with growth rate or specific productivity. This lack of relationship may be related to temporal differences in the nutrients limiting bacteria growth, including $\mathrm{C}$ of photosynthetic origin, although the potential influence of predators (e.g. protozoa) or mixotrophic flagellates (e.g. Chrysophyceae) (Nygaard \& Tobiesen 1993) should not be ruled out.

\section{Response of phytoplankton and bacteria to pulsed nutrients}

Nutrient pulses can range in size from zooplankton excretion processes to storm events, whose impact on nutrient dynamics is of special interest in the present work. A recent study in the small high mountain lakes of Sierra Nevada associated a sharp decrease in TN:TP towards the middle of the growing season with the influence of episodes bearing Saharan dust (Morales-Baquero et al. 1999), which are characterized by low N:P ratios (Talbot et al. 1986). During the present study, rain depositions were sporadic events that occurred with a relatively random frequency. Our results agree with previous works that emphasized the major role of the atmosphere in promoting biological activity in aquatic ecosystems (Krom et al. 1991), especially noticeable during the wet, more oligotrophic years of 1996 and 1997.

In an attempt to determine how these allochthonous inputs influenced bacterial and phytoplankton communities and the relationship between them, 2 nutrient enrichment experiments were performed at 2 distinct periods in the biological activity of the lake. Addition of $\mathrm{P}$ revealed the importance of the $\mathrm{N}: \mathrm{P}$ ratio of phytoplankton and bacteria to their relationship. Phytoplankton production was only stimulated when the $\mathrm{N}: \mathrm{P}$ ratio supplied was lower than that of the phytoplankton (i.e. excess of $\mathrm{P}$ relative to cellular demands). However, in the case of bacteria this response was also modulated by the interaction with phytoplankton, and specifically by the photosynthetic carbon release when phytoplankton is P-limited. Thus, when we experimentally added $\mathrm{P}$ to a P-limited phytoplankton population in August $\left(\mathrm{N}: \mathrm{P}_{\mathrm{p}} \approx 22\right.$; criteria of P-deficiency by Healey \& Hendzel 1980), photosynthesis and growth became highly coupled (sensu Berman-Frank \& Dubinsky 1999), phytoplankton grew at high rates (Fig. 7), and a decrease in PER was observed. Under such circumstances, PER barely met bacterial requirements for $\mathrm{C}$ in the nutrient treatments $\left(\mathrm{PER} \leq \mathrm{BGR}_{0.09 / 0.3 i}\right.$ Fig. 8), presumably restraining bacterial growth after a $\mathrm{P}$ amendment (Fig. 7).

Consistent with the above sequence, we observed that the $\mathrm{P}$ contained in the phytoplankton fraction greatly exceeded that in the bacterial fraction after an atmospheric deposition event. Because these events frequently occur in midsummer, when phytoplankton is growing in a nutrient-depleted environment, it can be hypothesized that nutrient pulses (both natural and experimental) greatly enhance the growth of phytoplankton over that of bacteria, ultimately diverting the flow of carbon from the microbial loop to grazing food 
webs (Berman-Frank \& Dubinsky 1999). Our observations are consistent with previous detected increments in lake chl a of about $100 \%$ following rain episodes carrying Sahara dust (Carrillo et al. 1990), or with the 5 -fold increase in autotrophic versus heterotrophic biomass after a nutrient input in a Mediterranean coastal community (Duarte et al. 2000). Furthermore, these results are in agreement with the prevailing idea of the higher capacity of algae to take advantage of high substrate concentrations (Tarapchak \& Moll 1990), in an ecologically advantageous mechanism that allows algae to rely on intermittent pulses of $\mathrm{P}$ associated with allochthonous loads (Cotner \& Wetzel 1992).

Conversely, addition of $\mathrm{P}$ to $\mathrm{P}$-sufficient phytoplankton in October ( $\left.\mathrm{N}: \mathrm{P}_{\mathrm{p}}=8.8\right)$ accelerated PER release. With plentiful carbon sources for growth

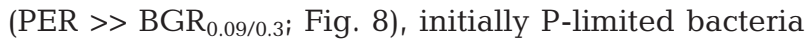
$\left(\mathrm{N}: \mathrm{P}_{\mathrm{b}}=47.5\right)$ responded with increased specific productivity to $\mathrm{P}$ amendments (Fig. 7). We interpret this
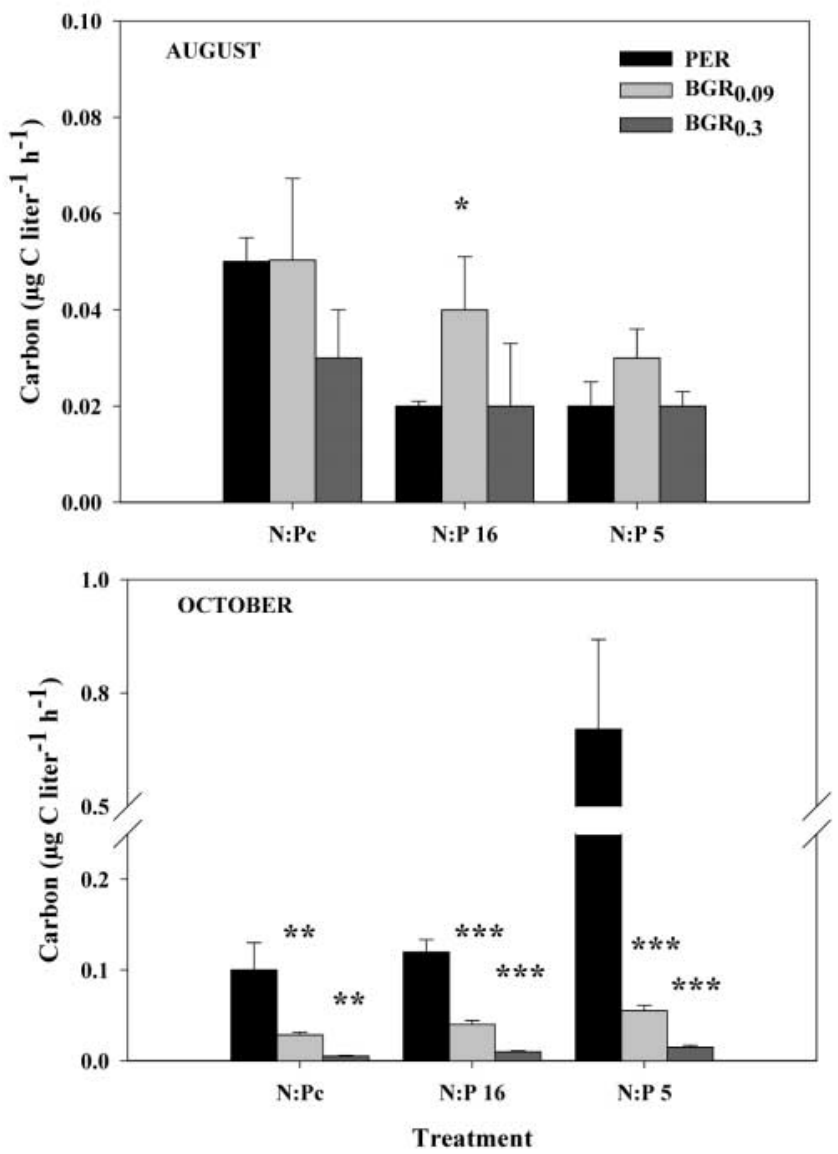

Fig. 8. Carbon excreted by phytoplankton (PER) and carbon required by bacteria (BGR) at a growth efficiency of 9 and $30 \%\left(\mathrm{BGR}_{0.09}\right.$ and $\mathrm{BGR}_{0.3}$, respectively) for August and October experiments. Differences between PER and BGR were tested by Tukey-tests. ${ }^{*} \mathrm{p}<0.05 ;{ }^{* *} \mathrm{p}<0.01 ;{ }^{* * *} \mathrm{p}<0.001$

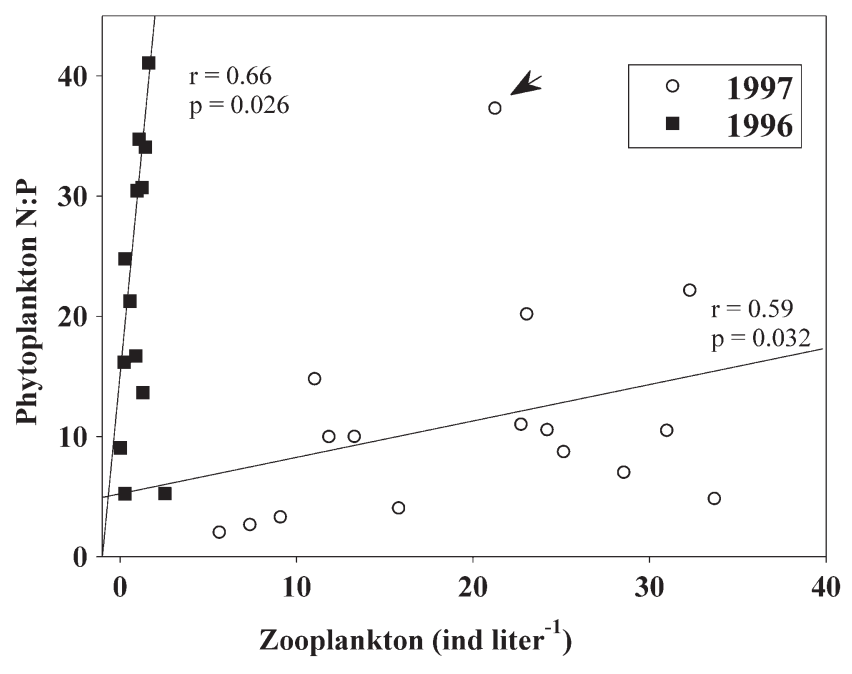

Fig. 9. Relationships between phytoplankton N:P ratio and zooplankton abundance in 1996 and 1997. Sample indicated with an arrow was not included in the regression analysis

response as the outcome of a competitive interaction. These results are consistent with many studies reporting a direct stimulation of bacterial growth by $\mathrm{P}$ addition (Elser et al. 1995, Brett et al. 1999), although an indirect stimulatory effect of increased PER from Psufficient phytoplankton (Wang et al. 1992) cannot be ruled out.

In summary, if phytoplankton $\mathrm{N}: \mathrm{P}$ is initially high (Pdeficient algae) after a $\mathrm{P}$ addition, PER is reduced and bacteria can experience $\mathrm{C}$ limitation, whereas if phytoplankton N:P is initially low (P-sufficient algae) and bacterial $\mathrm{N}: \mathrm{P}$ high (P-deficient bacteria), $\mathrm{P}$ addition is most likely to produce competition for the inorganic $\mathrm{P}$. We propose that in autotrophic systems such as La Caldera (Reche et al. 2001), bacteria temporally shift between a commensalistic interaction with phytoplankton (limitation by photosynthetic-produced dissolved organic carbon) and one of competition with phytoplankton for the available $\mathrm{P}$, depending on phytoplankton N:P ratio. Likewise, these results add to the increasing recognition that factors limiting production in bacteria and phytoplankton assemblages are likely to change over temporal scales (Caron et al. 2000). In addition, the present study emphasizes the importance of atmospheric P loads in determining the fate of the interaction between phytoplankton and bacteria in highly oligotrophic systems.

\section{CONCLUSIONS}

Droughts and atmospheric nutrient loads directly influence lake nutrient budgets, promoting biological 
production and leading to significant annual and seasonal variations of lake trophic state, respectively. A combination of climatic factors and internal biological factors, such as food web structure, drive the variability in the dynamics and nutrient composition of phytoplankton and bacteria.

In the lake under study, algae largely dominated $\mathrm{P}$ uptake at above ambient-P concentrations after a natural or experimental nutrient pulse. Thus, atmospheric loads were responsible for 66 to $526 \%$ increases in phytoplankton P biomass and 30 to $186 \%$ increases in bacterial P biomass. The present findings also suggest that knowledge of the elemental composition of bacteria, unlike that of phytoplankton, does not translate into reliable evidence of bacterial growth measured as specific productivity. Knowledge of the availability of photosynthetic $\mathrm{C}$ appears crucial to effectively interpret bacterial dynamics. In this autotrophic lake, information on the elemental composition of phytoplankton, corroborated by production bioassays, may be used to understand and predict patterns of coupled and uncoupled production in pelagic bacteria and phytoplankton after P pulses.

Acknowledgements. The authors gratefully acknowledge the help of the laboratory crew in routine sampling and Dr. Biddanda's generous contribution on a previous version of this manuscript. We also thank the 'Agencia del Medio Ambiente' for permission to access Lake La Caldera located in the National Park of Sierra Nevada, and Cetursa S.A. for providing the rainfall dataset. This work was supported by CICYT Project (AMB97-996), EC Environment MOLAR Project (ENV4-CT95-0007), and by a pre-doctoral MEC grant to M.V.-A. and to J.M.M.-S.

\section{LITERATURE CITED}

Aebischer NJ, Coulson JC, Colebrook JM (1990) Parallel long-term trends across four marine trophic levels and weather. Nature 347:753-755

APHA (1992) Standard methods for the examination of water and wastewater, 18th edn. American Public Health Association, Washington, DC

Bell WH, Sakshaug E (1980) Bacterial utilization of algal extracellular products. 2. A kinetic study of natural populations. Limnol Oceanogr 25:1021-1033

Berman-Frank I, Dubinsky Z (1999) Balanced growth in aquatic plants: myth or reality? Bioscience 49:29-37

Biddanda BA, Ogdahl M, Cotner J (2001) Dominance of bacterial metabolism in oligotrophic relative to eutrophic waters. Limnol Oceanogr 46:730-739

Botrell HH, Duncan A, Gliwicz ZM, Grygierek E and 5 others (1976) A review of some problems in plankton production studies. Norw J Zool 24:419-456

Brett MT, Lubnow FS, Villar-Argaiz M, Müller-Solger A, Goldman CR (1999) Nutrient control of bacterioplankton and phytoplankton dynamics. Aquat Ecol 33:135-145

Caron DA, Lin Lim E, Sanders RW, Dennett MR, Berninger UG (2000) Responses of bacterioplankton and phytoplankton to organic carbon and inorganic nutrient addi- tions in contrasting oceanic ecosystems. Aquat Microb Ecol 22:175-184

Carrillo P, Cruz-Pizarro L, Morales-Baquero R (1990) Effects of unpredictable atmospheric allocthonous inputs on the light climate of an oligotrophic lake. Verh Int Ver Limnol 24:97-105

Carrillo P, Reche I, Sanchez-Castillo P, Cruz-Pizarro L (1995) Direct and indirect effects of grazing on the phytoplankton seasonal succession in an oligotrophic lake. J Plankton Res 17:1363-1379

Carrillo P, Reche I, Cruz-Pizarro L (1996) Intraspecific stoichiometric variability and the ratio of nitrogen to phosphorus resupplied by zooplankton. Freshw Biol 36: 363-374

Carrillo P, Villar-Argaiz M, Medina-Sánchez JM (2001) Relationship between N:P ratio and growth rate during the life cycle of calanoid copepods: an in situ measurement. J Plankton Res 23:537-547

Carrillo P, Medina-Sánchez JM, Villar-Argaiz M (2002) The interaction of phytoplankton and bacteria in a high mountain lake: importance of the spectral composition of solar radiation. Limnol Oceanogr 47:1294-1306

Chrzanowski TH, Kyle M, Elser JJ, Sterner RW (1996) Element ratios and growth dynamics of bacteria in an oligotrophic Canadian shield lake. Aquat Microb Ecol 11: 119-125

Cole JJ, Likens GE, Strayer DL (1982) Photosynthetically produced dissolved organic carbon: an important carbon source for planktonic bacteria. Limnol Oceanogr 27: 1080-1090

Cole JJ, Caraco NF, Likens GE (1990) Short-range atmospheric transport: a significant source of phosphorus to an oligotrophic lake. Limnol Oceanogr 35:1230-1237

Cotner JB, Wetzel RG (1992) Uptake of dissolved inorganic and organic phosphorus compounds by phytoplankton and bacterioplankton. Limnol Oceanogr 37:232-243

Cotner JB, Johengen TH, Biddanda BA (2000) Intense winter heterotrophic production stimulated by benthic resuspension. Limnol Oceanogr 45:1672-1676

Currie DJ, Kalff J (1984) A comparison of the abilities of freshwater algae and bacteria to acquire and retain phosphorus. Limnol Oceanogr 29:298-310

del Giorgio PA, Gasol JM (1995) Biomass distribution in freshwater plankton communities. Am Nat 146:135-152

Duarte CM, Agustí S, Gasol JM, Vaqué D, VazquezDominguez E (2000) Effect of nutrient supply on the biomass structure of planktonic communities: an experimental test on a Mediterranean coastal community. Mar Ecol Prog Ser 206:87-95

Echevarría F, Carrillo P, Jimenez F, Sánchez-Castillo P, CruzPizarro L, Rodríguez J (1990) The size abundance distribution and taxonomic composition of plankton in an oligotrophic, high mountain lake (La Caldera, Sierra Nevada, Spain). J Plankton Res 12:415-422

Elser JJ, Chrzanowski TH, Sterner RW, Schampel JH, Foster DK (1995) Elemental ratios and the uptake and release of nutrients by phytoplankton and bacteria in three lakes of the Canadian Shield. Microb Ecol 29:145-162

Fagerbakke KM, Heldal M, Norland S (1996) Content of carbon, nitrogen, oxygen, sulfur and phosphorus in native aquatic and cultured bacteria. Aquat Microb Ecol 10: $15-27$

Fuhrman JA, Azam F (1982) Thymidine incorporation as a measure of heterotrophic bacterioplankton production in marine surface waters: evaluation and field results. Mar Biol 66:109-120

Gasol JM, del Giorgio PA, Duarte CM (1997) Biomass distrib- 
ution in marine planktonic communities. Limnol Oceanogr 42:1353-1363.

Healey FP, Hendzel LL (1980) Physiological indicators of nutrient deficiency in lake phytoplankton. Can J Fish Aquat Sci 37:442-453

Hessen DO, Andersen T (1992) The algae-grazer interface: feedback mechanisms linked to elemental ratios and nutrient cycling. Arch Hydrobiol 35:111-120

Houghton JT, Meira Filho LG, Callander BA, Harris N, Kattenberg A, Maskell K (1996) IPCC [Intergovernmental Panel on Climate Change]. Climate Change 1995. The Science of Climate Change. Cambridge University Press, Cambridge

Jeffrey SW, Humphrey GF (1975) New spectrophotometric equations for determining chlorophyll $a, b, \mathrm{c} 1$ and $c 2$ in higher plants, algae and natural phytoplankton. Biochem Physiol Pflanz 167:191-194

Kreeger DA, Goulden CE, Kilham SS, Lynn SG, Datta S, Interlandi SJ (1997) Seasonal changes in the biochemistry of lake seston. Freshw Biol 38:539-554

Kristiansen K, Nielsen H, Riemann B, Fuhrman JA (1992) Growth efficiencies of freshwater bacterioplankton. Microb Ecol 24:145-160

Krom MD, Crees N, Brenner S, Gordon LI (1991) Phosphorus limitation of primary productivity in the eastern Mediterranean Sea. Limnol Oceanogr 36:424-432

Lee S, Fuhrman JA (1987) Relationships between biovolume and biomass of naturally derived marine bacterioplankton. Appl Environ Microbiol 53:1298-1303

Lignell R (1992) Problems in filtration fractionation of ${ }^{14} \mathrm{C}$ primary productivity samples. Limnol Oceanogr 37:172-178

Löye-Pilot MD, Martin JM, Morelli J (1986) Influence of Saharan dust on the rain acidity and atmospheric input to the Mediterranean. Nature 321:427-428

Marsh P, Lesack LFW (1996) The hydrologic regime of perched lakes in the Mackenzie Delta: potential responses to climate change. Limnol Oceanogr 41:849-856

Medina-Sánchez JM, Villar-Argaiz M, Sánchez-Castillo P, Cruz-Pizarro L, Carrillo P (1999) Structure changes in a planktonic food web: biotic and abiotic controls. J Limnol 58:213-222

Morales-Baquero R, Carrillo P, Reche I, Sánchez-Castillo P (1999) Nitrogen-phosphorus relationship in high mountain lakes: effects of the size of catchment basins. Can J Fish Aquat Sci 51:1809-1817

Norland S (1993) The relationship between biomass and volume of bacteria. In: Kemp PF, Sherr BF, Sherr EB, Cole JJ (eds) Handbook of methods in aquatic microbial ecology. Lewis Publishers, Boca Raton, p 303-307

Nygaard K, Tobiesen A (1993) Bacterivory in algae - a survival strategy during nutrient limitation. Limnol Oceanogr 38:273-279

Olsen Y, Varum KM, Jensen A (1986) Dependence on the rate of release of phosphorus by zooplankton on the $\mathrm{P}: \mathrm{C}$ ratio in the food supply, as calculated by the recycling model. Limnol Oceanogr 31:34-44

Polis GA, Winemiller KO (1996) Food webs, interaction of patterns and dynamics. Chapman \& Hall, New York

Porter KG (1996) Integrating the microbial loop and the classic food chain into a realistic planktonic food web. In: Polis GA, Winemiller, KO (eds) Food webs, interaction of patterns and dynamics. Chapman \& Hall, New York, p 72-80

Porter KG, Feig YS (1980) Use of DAPI for identifying and counting aquatic microflora. Limnol Oceanogr 25:943-948

Editorial responsibility: Frede Thingstad,

Bergen, Norway
Psenner R (1999) Living in a dusty world — airborne dust as a key factor for Alpine Lakes. Water Air Soil Pollut 112:217-227

Reche I, Pugnetti A, Cruz-Pizarro L, Carrillo P (1996) Relationship between bacteria and phytoplankton in a highmountain lake: importance of the organic carbon released by pelagic algae for bacterioplankton. Arch Hydrobiol 48:31-38

Reche I, Pulino-Villena E, Conde-Porcuna JM, Carrillo P (2001) Photoreactivity of dissolved organic matter from high-mountain lakes of Sierra Nevada, Spain. Art Ant Alp Res 33:426-434

Rocha O, Duncan A (1985) The relationship between cell carbon and cell volume in freshwater algal species used in zooplankton studies. J Plankton Res 7:279-294

Ruttner-Kolisko A (1997) Suggestion for biomass calculations of plankton rotifers. Arch Hydrobiol 8:71-76

StatSoft Inc (1997) Statistica for Windows. Release 5.1, Tulsa

Steemann-Nielsen E (1952) The use of radioactive carbon $\left({ }^{14} \mathrm{C}\right)$ for measuring organic production in the sea. J Cons Int Explor Mer 18:117-140

Sterner RW (1995) Elemental stoichiometry of species in ecosystems. In: Jones C, Lawton J (eds) Linking species and ecosystems. Chapman \& Hall, New York, p 240-252

Straile D (2000) Meteorological forcing of plankton dynamics in a large and deep continental European lake. Oecologia 122:44-50

Straskrabová V, Callieri C, Carrillo P, Cruz-Pizarro L and 6 others (1999) Investigations on pelagic food webs in mountain lakes - aims and methods. J Limnol 58:77-87

Talbot RW, Harris RC, Browell EV, Gregory GL, Sebacher DI, Beck SM (1986) Distribution and geochemistry of aerosols in the Tropical North Atlantic troposphere: relationships to Saharan dust. J Geophys Res 91(D4):5173-5182

Tarapchak SJ, Moll RA (1990) Phosphorus sources for phytoplankton and bacteria in Lake Michigan. J Plankton Res 12:743-758

Tezuka Y (1990) Bacterial regeneration of ammonia and phosphate as affected by the carbon:nitrogen:phosphorus ratio of organic substrates. Microb Ecol 19:227-238

Thingstad TF, Skjoldal EF, Bohne RA (1993) Phosphorus cycling and algal-bacterial competition in Sadsfjord, western Norway. Mar Ecol Prog Ser 99:239-259

Torreton JP, Bouvy M (1991) Estimating bacterial DNA synthesis from ${ }^{3} \mathrm{H}$-thymidine incorporation: discrepancies among macromolecular extraction procedures. Limnol Oceanogr 36:299-306

Vadstein O, Olsen Y (1989) Chemical composition and phosphate uptake kinetics of limnetic bacterial communities cultured in chemostats under phosphorus limitation. Limnol Oceanogr 34:939-946

Villar-Argaiz M, Medina-Sánchez JM, Cruz-Pizarro L, Carrillo P (2001) Inter- and intra-annual variability in the phytoplankton community of a high mountain lake: the influence of external (atmospheric) and internal (recycled) sources of P. Freshw Biol 46:1017-1034

Villar-Argaiz, M, Medina-Sánchez JM, Carrillo P (2002) Linking life history strategies and ontogeny in crustacean zooplankton: implications for homeostasis. Ecology 58: 1899-1914

Wang L, Miller TD, Priscu JC (1992) Bacterioplankton nutrient deficiency in a eutrophic lake. Arch Hydrobiol 125:423-439

Wetzel RG, Likens GE (1991) Limnological analyses. Springer-Verlag, New York

Submitted: March 20, 2002; Accepted: June 24, 2002

Proofs received from author(s): September 19, 2002 